\title{
Identification and properties of a keratinase from Stenotrophomonas maltophilia N4 with potential application in biotechnology
}

\author{
Urszula Jankiewicz $^{1^{*}}$, Magdalena Frąk ${ }^{2}$ \\ ${ }^{1}$ Department of Biochemistry, Faculty of Agriculture and Biology, Warsaw University of Life Sciences - SGGW, \\ Nowoursynowska 166 St, 02-787 Warsaw, Poland, \\ e-mail: urszula_jankiewicz@sggw.pl \\ ${ }^{2}$ Faculty of Civil and Environmental Engineering, Warsaw University of Life Sciences - SGGW, \\ Nowoursynowska 166 St, 02-787 Warsaw, Poland
}

Received: 13 September 2017 /Accepted: 21 November 2017

\begin{abstract}
The bacterium Stenotrophomonas maltophilia N4 produces different extracellular proteases when cultured in a mineral medium with $1 \%$ of bird feathers. One of the enzymes was purified and characterized. The studied enzyme is a peptidase with keratinolytic activity. The optimal temperature for enzyme activity of the purified protein is $60^{\circ} \mathrm{C}$, and its $\mathrm{pH}$ optimum 8.5 . Its thermal stability is approximately $50 \%$ after two hours of preincubation at $55^{\circ} \mathrm{C}$. Enzymatic activity is strongly inhibited by DFP and EDTA, indicating that the enzyme belongs to the metal-dependent serine proteases. Calcium, magnesium and manganese ions enhance the activity of the studied keratinase. The enzyme has broad substrate specificity; it hydrolyzes not only keratin, but also casein, gelatin and hemoglobin Considering the fact that the N4 bacteria are capable of using bird feathers as a source of organic nitrogen and carbon, and bearing in mind the stability and the broad substrate specificity of the studied enzyme, it appears that it may find application in various branches of biotechnology.
\end{abstract}

Key words: extracellular protease, feather degradation, keratinase, enzyme purification, Stenotrophomonas maltophilia.

\section{Introduction}

Proteolytic enzymes, also known as peptidases, proteases or proteinases, have always been a relevant and valid study subject. The considerable interest in bacterial proteolytic enzymes largely results from the possibilities of their application. Such enzymes are commonly used in biotechnology due to their biochemical diversity, high stability under unfavorable reaction conditions, relatively low cost of obtaining, and the ease of their genetic manipulation (Rao et al., 1998; Sawant \& Nagendran, 2014; Vojcic et al., 2015). The enzymes, which hydrolyze peptide bonds that link amino acids together in the polypeptide chain forming a protein, may be used to remove protein waste, particularly including protein waste that is insoluble in water and therefore degrades more slowly in the natural environment. Keratin-rich by-products such as bird feathers, horns, the epidermis and the hair of animals, are an instance of such proteins with low hydrolytic susceptibility. They are a heterogeneous group of fibrous proteins with particularly low susceptibility to chemical and enzymatic hydrolysis (Brandelli et al., 2010; Gupta \& Ramnani, 2006; Gupta et al., 2013). These proteins are resistant to hydrolysis because of their tight structure, which is supported primarily by cysteine bridges, and also by hydrogen bonds and hy- 
drophobic interactions (Bockle \& Muller, 1997; Gopinath et al., 2015). However, the interest of science in keratin hydrolysis relates not only to the effective removal of the waste of insoluble protein polymers from the environment; it is also about the possibility of obtaining keratin, a valuable cosmetic and pharmaceutical ingredient, that is at the center of researchers' interest in this aspect (Lasekan et al., 2013; Fontoura et al., 2014) Attempts have also been made to use keratin wastes as a source of bioactive peptides and agricultural fertilizers (Brandelli et al., 2015). Keratinases [EC 3.4.21/24/99.11] are responsible for the enzymatic hydrolysis of the discussed group of proteins. In addition to hydrolyzing fibrous proteins, keratinolytic enzymes also hydrolyze collagen and non-fibrous proteins such as casein and albumin, thus pointing to the enzymes' broad substrate specificity (Gupta \& Ramnani, 2006). A multitude of cysteine bridges in the keratin molecule suggests that sulfite reductases or reducing compounds participate in the initial stage of hydrolysis (Korniłłowicz-Kowalska \& Bohacz, 2011; Prakash et al., 2010). Keratinolytic microorganisms include many types of microorganisms, including a large number of species from the genera: Bacillus, Streptomyces, Lysobacter and Vibrio (Laba et al., 2015; Brandelli, 2008). The bacterium Stenotrophomonas maltophilia is also capable of the effective degradation of bird feathers and depilation of animal skins (Yamamura et al., 2002; Cao et al., 2009; Jeong et al., 2010). Stenotrophomonas maltophilia N4 is one of its strains; it has high proteolytic activity and is the source of the enzyme that is discussed in this paper.

The main purpose of the study was to isolate and characterize one of the proteolytic enzymes released by the bacterium in terms of optimal activity, substrate specificity, the effect of inhibitors and metal ions. In order to evaluate the usefulness of the protein in biotechnology, diverse substrates were used and the enzyme's activity was studied during its reaction in the presence of non-ionic detergents.

\section{Materials and methods}

\subsection{Bacterial culture conditions and enzyme activity analysis}

Stenotrophomonas maltophilia N4 (accession number: AB667906) was the source of proteases in the presented study. Bacteria were grown for $72 \mathrm{~h}$ with shaking at $120 \mathrm{rpm}$ and temperature $28^{\circ} \mathrm{C}$. Bacterial cultures were grown in mineral medium composed of ( $\mathrm{g} /$ liter): $\mathrm{KH}_{2} \mathrm{PO}_{4}$, $3 ; \mathrm{K}_{2} \mathrm{HPO}_{4}, 3 ; \mathrm{MgSO}_{4}, 0.5 ; \mathrm{NaCl}, 2 ; \mathrm{FeCl}_{3}, 0.005$. In order to optimize the composition of the culture medium, the following ingredients were used separately or in combinations as supplements $(\mathrm{g} / \mathrm{L})$ : feathers 10 , yeast extract 2.5 , Bacto Peptone 5, glucose 5. Control culture media did not contain the feathers. The covert feathers of the helmeted guineafowl (Numida meleagris) were obtained from the Poultry Breeding Division at WULS. Before they were added to the medium and autoclaved, the feathers were cleaned and split into approximately $2 \mathrm{~cm}$ fragments.

Keratinolytic activity was measured using a modified protocol by Cai et al. (2008) using $5 \mathrm{mg}$ keratin azure as the substrate suspended in $50 \mathrm{mM}$ Tris- $\mathrm{HCl}$ buffer $\mathrm{pH} 8.5$. Enzymatic reaction was carried out for 1 hour at $40^{\circ} \mathrm{C}$ with constant agitation at $200 \mathrm{rpm}$. One unit of keratinase activity $(\mathrm{U})$ was the amount of enzyme that caused a change in absorbance of 0.01 at $595 \mathrm{~nm}$ after reaction for $1 \mathrm{~h}$.

Caseinolytic activity was determined using the Anson method (1938) a with $1 \%$ casein solution in $50 \mathrm{mM}$ Tris$\mathrm{HCl}$ buffer $\mathrm{pH}$ 8.0. The enzymatic reaction was carried out for $30 \mathrm{~min}$ at the temperature of $40^{\circ} \mathrm{C}$. One unit of caseinolytic activity $(\mathrm{U})$ was defined as the amount of enzyme required to liberate $1 \mu$ mole of tyrosine within $30 \mathrm{~min}$ of the reaction under the specified conditions.

\subsection{Enzyme purification and proteomic analysis with mass spectrometry (MS)}

All protein purification stages were performed at the temperature of $4^{\circ} \mathrm{C}$. In order to obtain a clear supernatant, filtering and subsequent centrifugation ( $9000 \mathrm{x}$ g for $10 \mathrm{~min}$ ) were carried out on the third day of bacterial culture in a mineral medium with $1 \%$ of bird feathers. The supernatant was precipitated using ammonium sulfate until $85 \%$ saturation was reached. The protein precipitate obtained after centrifugation was then dissolved in $20 \mathrm{mM}$ Tris- $\mathrm{HCl}$ buffer with $\mathrm{pH} 7.8$ and dialyzed against the same buffer for 12 hours, with two changes of the buffer. The preparation after dialysis was separated on a column of DEAESepharose (Sigma), which was equilibrated with $20 \mathrm{mM}$ Tris-HCl buffer $\mathrm{pH}$ of 8.0. Proteins that bound to the anion exchanger were eluted in a gradient of 0 to $0.5 \mathrm{M} \mathrm{NaCl}$. Fractions ( $5 \mathrm{ml}$ volume) were screened for keratinolytic and caseinolytic activity. The protein fractions that were obtained after ion-exchange chromatography and had the highest activity were concentrated, resulting in approximately $30-50 \mu \mathrm{g} / \mathrm{mL}$ protein in the preparation. The protein samples previously digested with trypsin were separated on a nanoAcquity UPLC (Ultra Performance LC) system and analyzed with an Orbitrap-based mass spectrometer (the Polish Academy of Sciences). The obtained results were analyzed using Blast software.

The fractions with highest keratinolytic activity were concentrated and then subjected to molecular sieve chromatography. The concentrated preparation (10-fold) was applied to a column of Superdex 200 (Sigma), which was equilibrated with $50 \mathrm{mM}$ Tris- $\mathrm{HCl}$ buffer, $\mathrm{pH}$ 8.0. Active fractions were used for characterizing the enzyme. 


\subsubsection{Protein determination and zymography analysis}

Protein concentration in samples was determined using the method of Bradford (1976) with bovine serum albumin as the protein standard.

Zymograms were obtained after in semi-native SDSPAGE electrophoretic separation (without thermal denaturation and $\beta$ - mercaptoethanol) of the samples in $10 \%$ polyacrylamide SDS gel with incorporating $0.1 \%$ casein (Laemmli, 1970, with modifications). On completion of electrophoresis the gels were incubated for $1 \mathrm{~h}$ in $0.5 \%$ Triton X-100 solution, and then transferred to 100 $\mathrm{mM}$ Tris- $\mathrm{HCl}$ buffer, $\mathrm{pH} 8.5$ and stained with $0.1 \%$ amide black solution. Proteolytic activity was observed as bright bands where the substrate was digested, against the dark blue background of the gel.

\subsection{Characterization of purified protease}

The optimal temperature was determined in the range from 30 to $65^{\circ} \mathrm{C}$. The optimum $\mathrm{pH}$ was determined in the range of $5.5-9.5$. The following buffer systems were used: $50 \mathrm{mM}$ Britton-Robinson buffer for the $\mathrm{pH}$ range $5.5-9.5$ and $50 \mathrm{mM}$ Tris- $\mathrm{HCl}$ buffer for the $\mathrm{pH}$ range $6.8-8.5$.

The substrate specificity of the enzyme was determined using the Anson (1938) method with 1\% solutions of substrates (gelatin, hemoglobin, casein, and soluble keratin).

In order to study the effect of specific proteases inhibitors on activity, the purified enzyme was preincubated with an inhibitor solution for $30 \mathrm{~min}$. at $4^{\circ} \mathrm{C}$, after which the remaining activity was tested. The effect of metal ions on the activity was determined following preincubation of the enzyme for $30 \mathrm{~min}$ at $4{ }^{\circ} \mathrm{C}$ in the presence of metal ions in final concentration of $5.0 \mathrm{mM}$, after which the substrate was added and the activity tested.

All results presented in this paper in the form of numerical values were means from 3 independent determinations. The mean error, reflecting maximal deviation of the results of measurements from the mean, did not exceed $5 \%$.

\section{Results}

\subsection{Bacterial culture and composition of growth medium}

The results of this study indicate that the bacterium $S$. maltophilia N4 was able to utilize bird feathers as a sole source of organic carbon and nitrogen in mineral medium (Fig. 1).

Enrichment of the culture medium containing 1\% feathers in yeast extract, glucose or peptone did not result in enhanced proteolytic activity. At the same time it was observed that the presence of feathers in the medium induced the activity of proteases, particularly in mineral medium with scant peptide components or in mineral medium with glucose (Fig. 2).

\subsection{Purification of protease, zymography and MS analysis}

The clear culture medium obtained after filtration and centrifugation of a 3 day bacterial culture in mineral medium containing $1 \%$ feathers was taken for the purification of proteases. Purification involved the following stages: fractionation with ammonium sulfate at $30-85 \%$ satura-

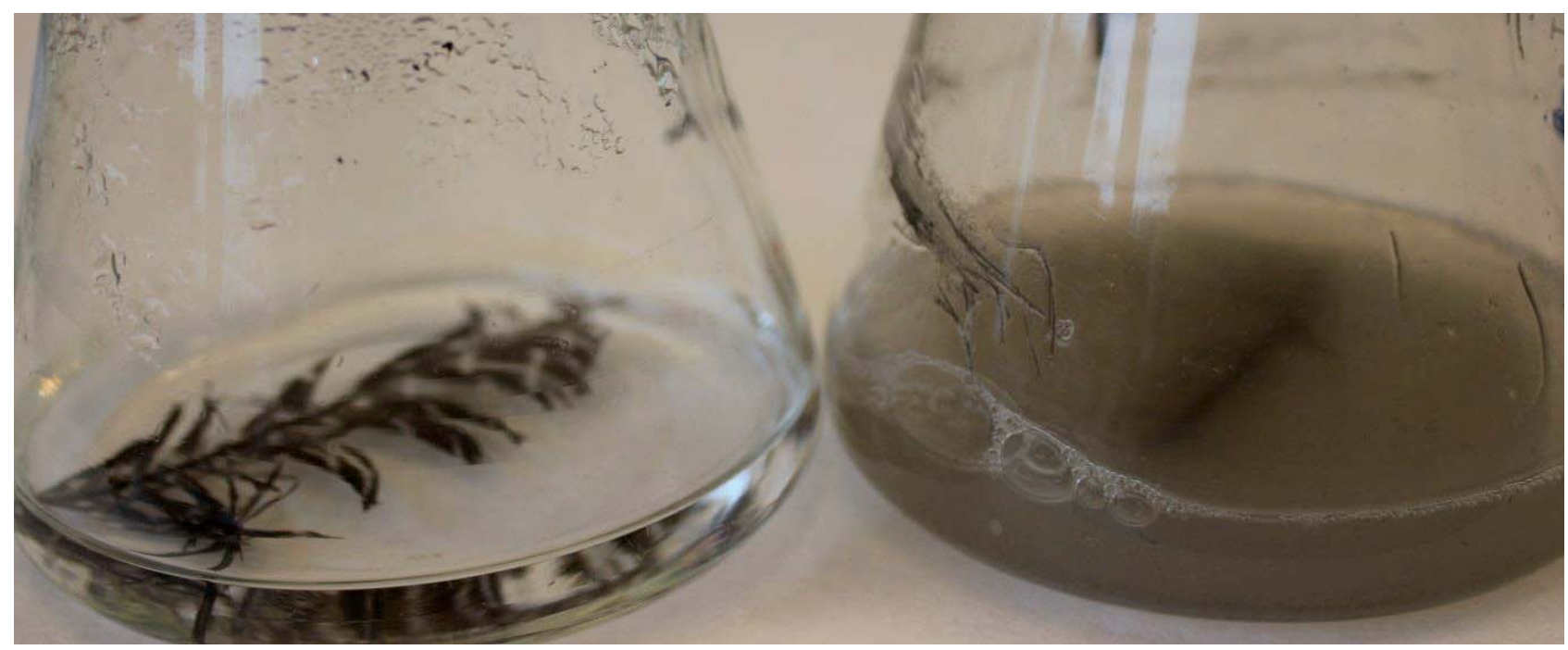

Figure 1. Feather degradation after $24 \mathrm{~h}$ of bacterial incubation 
tion, ion-exchange chromatography and molecular sieve chromatography (Table 1).

Ion-exchange chromatography yielded three main peaks of caseinolytic and keratinolytic activity as presented in Figure 3.

The three protease fractions obtained as a result of this stage of purification were subject to proteomic analysis us- ing mass spectrometry. The identified proteolytic enzymes included metal-dependent endoproteases and serine endoproteases (details in Table 2, supplementary materials).

In the third fraction, eluted at about $0.35 \mathrm{M} \mathrm{NaCl}$, peptides having a consensus sequence with a serine peptidase

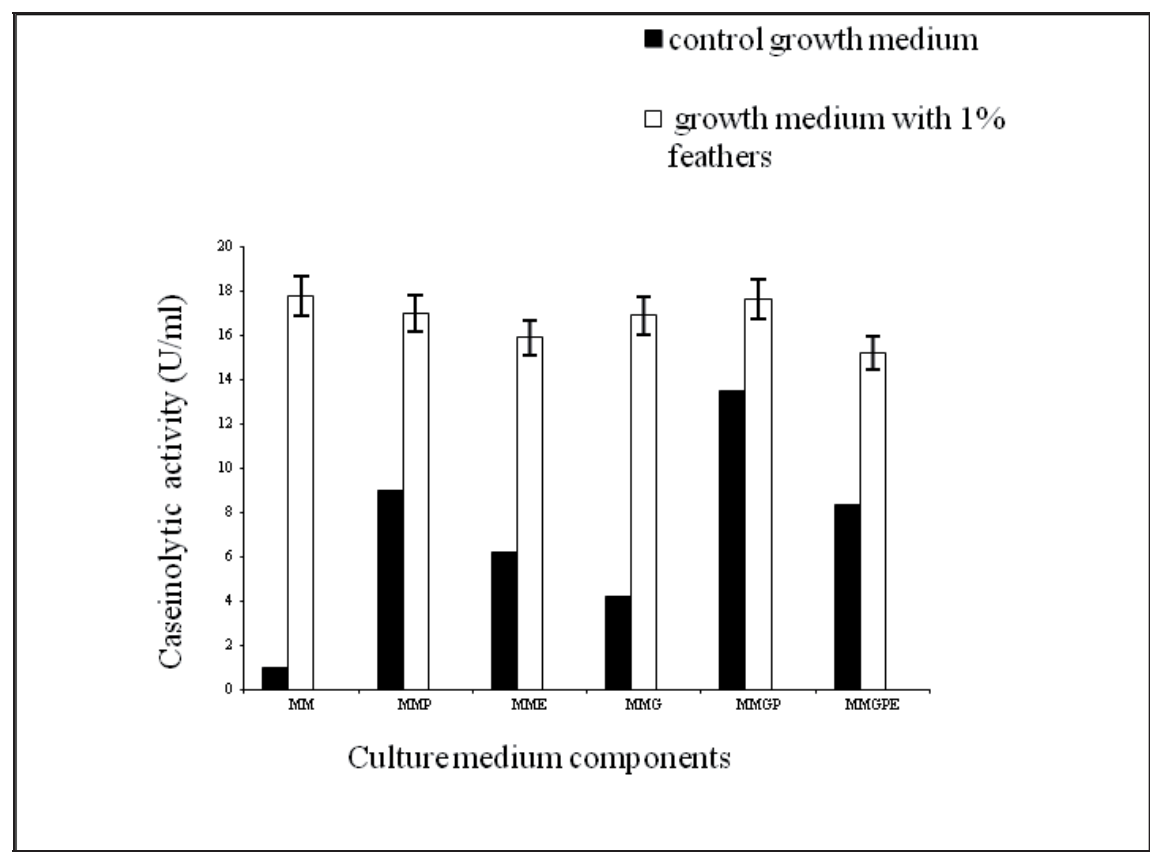

Figure 2. Proteolytic activity on the third day of bacterial culture. The following media were used: MM - mineral medium , MMP - mineral medium supplemented with peptone, MME - mineral medium supplemented with yeast extract, MMG - mineral medium supplemented with glucose, MMGP mineral medium supplemented with peptone and glucose, MMGPE mineral medium supplemented with peptone, glucose and yeast extract. Control culture media did not contain the feathers

Table 1. Purification of keratinase from S. maltophilia N4

\begin{tabular}{|l|c|c|c|c|c|}
\hline \multicolumn{1}{|c|}{ Purification step } & $\begin{array}{c}\text { Total activity } \\
{[\mathbf{U}]}\end{array}$ & $\begin{array}{c}\text { Total } \\
\text { protein } \\
{[\mathbf{m g}]}\end{array}$ & $\begin{array}{c}\text { Specific } \\
\text { activity } \\
{[\mathbf{U} / \mathbf{m g}]}\end{array}$ & $\begin{array}{c}\text { Recovery } \\
\text { [\%] }\end{array}$ & Purification fold \\
\hline Cell free supernatant & 8100 & 454 & 17.8 & 100 & 1 \\
\hline $\begin{array}{l}\text { Ammonium sulfate precipitation } \\
(30-85 \%)\end{array}$ & 5900 & 290 & 20.3 & 72.84 & 1.14 \\
\hline DEAE Sepharose $(0-0.5 \mathrm{M} \mathrm{NaCl})$ & 1700 & 18 & 94.4 & 21 & 4.8 \\
\hline Superdex 200 & 1000 & 4.3 & 232.6 & 12.3 & 13.1 \\
\hline
\end{tabular}



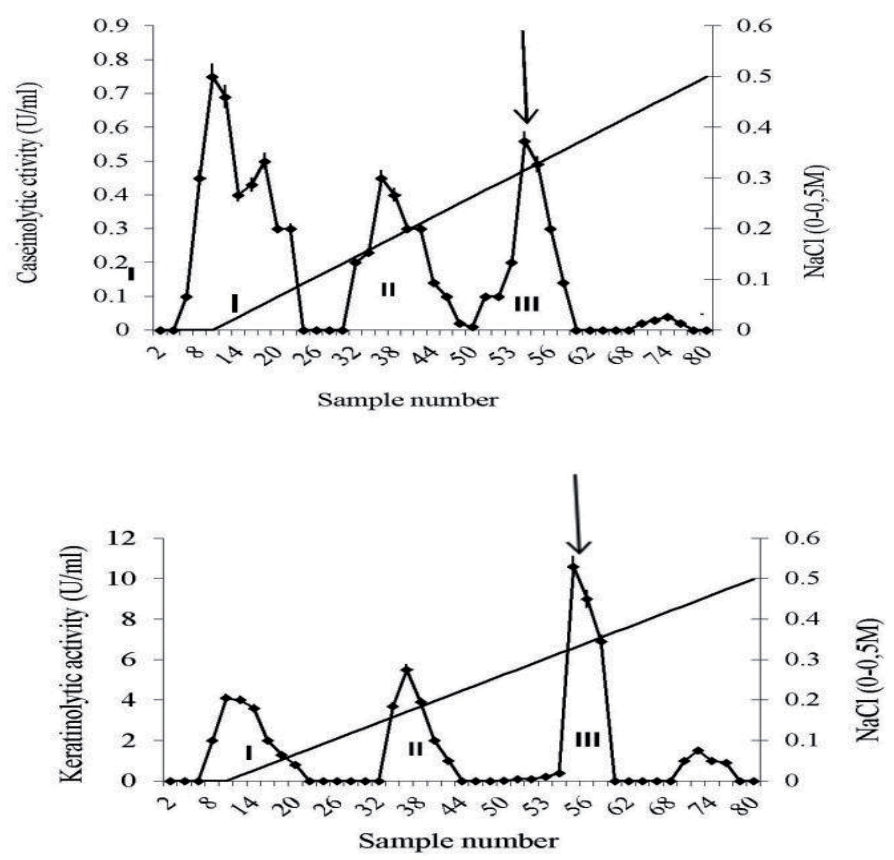

Figure 3. Ion-exchange chromatography of the proteases from S. maltophilia N4

Table 2. Mass spectrometry identification of proteases of S. maltophilia N4 in Fractions I, II, III after separation by ion exchange chromatography

\begin{tabular}{|c|c|c|c|}
\hline Fraction of proteases & Identification of the protease & $\begin{array}{l}\text { Microorganism /Accession } \\
\text { Number in Genbank }\end{array}$ & Catalytic Type \\
\hline \multirow{3}{*}{$\begin{array}{l}\text { Proteases not binding } \\
\text { to the bed, eluted at } \\
\text { equilibrium buffer }\end{array}$} & $\begin{array}{c}\text { Peptidyl-Asp } \\
\text { metalloendopeptidase }\end{array}$ & $\begin{array}{l}\text { Stenotrophomonas maltophilia } \\
\text { R551-3/ GenBank/ACF50520, }\end{array}$ & $\begin{array}{l}\text { Metallopeptidase family } \\
\text { (M12B family) }\end{array}$ \\
\hline & Aminopeptidase & $\begin{array}{c}\text { Stenotrophomonas maltophilia } \\
\text { R551-3]/ } \\
\text { ACF50006 }\end{array}$ & $\begin{array}{l}\text { Metalloexopeptidase } \\
\text { (M28 family) }\end{array}$ \\
\hline & Serine Peptidase StmPr1 & $\begin{array}{l}\text { Stenotrophomonas maltophilia } \\
\text { R551-3] }\end{array}$ & $\begin{array}{l}\text { Serine protease } \\
\text { (S8 family) }\end{array}$ \\
\hline \multirow{2}{*}{$\begin{array}{l}\text { F II } \\
\text { Proteases binding to the } \\
\text { bed; eluted at around } \\
0.22-0.25 \mathrm{M} \mathrm{NaCl}\end{array}$} & $\begin{array}{l}\text { Dipeptidyl peptidase IV Alanyl } \\
\text { dipeptidyl peptidase }\end{array}$ & $\begin{array}{c}\text { Stenotrophomonas maltophilia } \\
\text { D457/ } \\
\text { CCH11727 }\end{array}$ & $\begin{array}{c}\text { Serine prolyl oligopeptidase, } \\
\text { (S9 family) }\end{array}$ \\
\hline & peptidase S8 (Pr2) & $\begin{array}{c}\text { Stenotrophomonas maltophilia/ } \\
\text { WP_025877979 }\end{array}$ & $\begin{array}{l}\text { Serine protease } \\
\text { (S8 family) }\end{array}$ \\
\hline $\begin{array}{l}\qquad \text { F III } \\
\text { Proteases strongly binding } \\
\text { to the bed; eluted at } \\
\text { around } 0.35 \mathrm{M} \mathrm{NaCl}\end{array}$ & Alkaline serine protease & $\begin{array}{c}\text { Stenotrophomonas maltophilia } \\
\text { OBGTC27/ } \\
\text { CBI67281 }\end{array}$ & $\begin{array}{l}\text { Serine peptidase } \\
\text { (S8 family, S8_53 } \\
\text { superfamily) }\end{array}$ \\
\hline
\end{tabular}


from Genbank (accession number CBI67281) were identified. This enzyme fraction was taken for further purification molecular sieve chromatography. Analysis of a zymogram run after this purification stage revealed the presence of a single activity band in the gel (Fig. 4). The final preparation contained a 13-fold purification enzyme, which was used in biochemical characterization steps.

\subsection{Biochemical characterization of protease N4}

The purified enzyme showed maximal activity at $60^{\circ} \mathrm{C}$ (Fig. 4).

The activity drastically decreased at higher temperatures and at $65^{\circ} \mathrm{C}$ only $70 \%$ of the maximal activity was observed. Optimal pH was about 8.5 , but similar enzymatic activity was observed even at pH 8.0 (Fig. 6).

The data in Table 3 illustrate that the highest activity of the enzyme, that is $2.25 \mathrm{U} \mathrm{ml}^{-1}$, was observed in the presence of casein and keratin, $1.6 \mathrm{U} \mathrm{ml}^{-1}$. This indicates that the $\mathrm{K}: \mathrm{C}$ ratio was 0.71 .

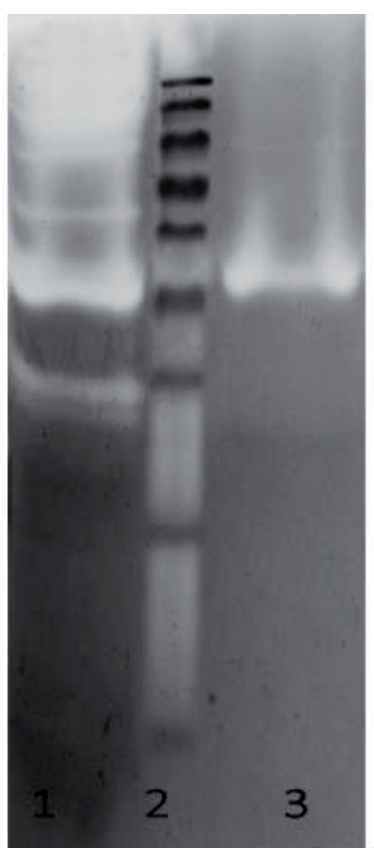

$36 \mathrm{kDa}$

Figure 4. Zymograms analysis of keratinase activity. 1 -crude enzyme preparation, 2 -protein ladder (Thermo Scientific Protein Ladder \#26616) 3- purified keratinase

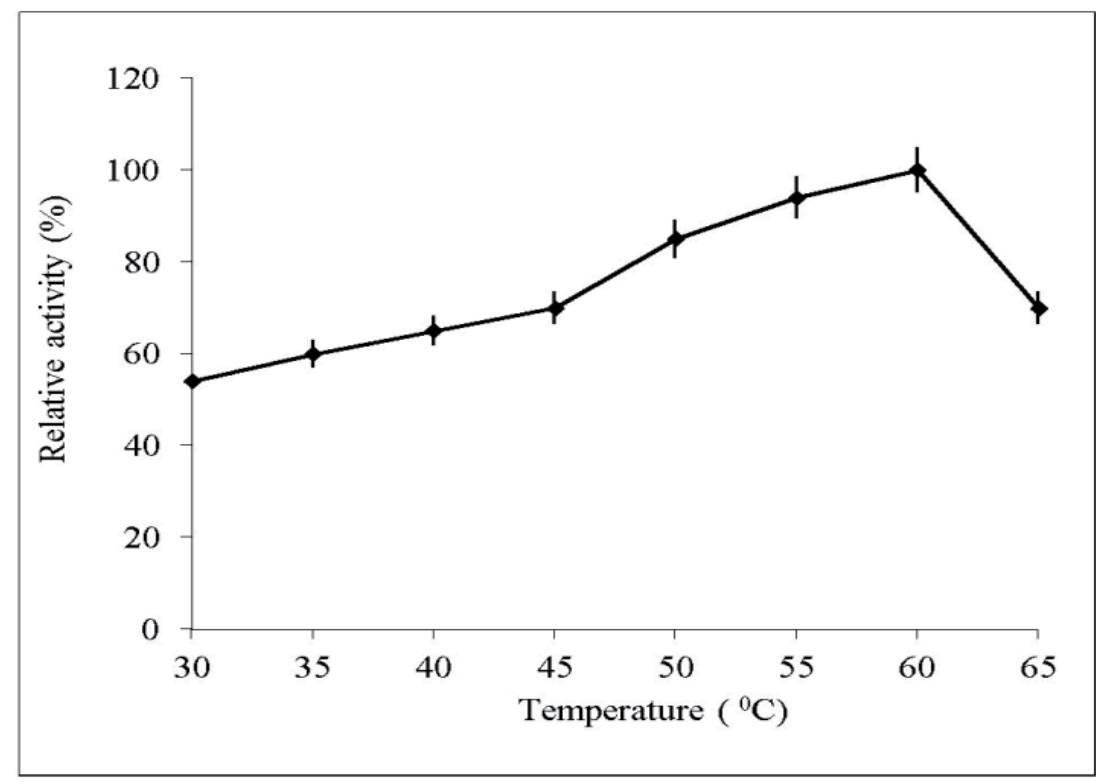

Figure 5. Effect of temperature on the activity of keratinase from S. maltophilia N4 
Table 3. Substrate preference of the keratinase

\begin{tabular}{|l|c|c|}
\hline Substrates & Activity (U/ml) & $\begin{array}{c}\text { Relative } \\
\text { activity (\%) }\end{array}$ \\
\hline Casein & 2.25 & 100 \\
\hline Keratin & 1.60 & 71 \\
\hline Hemoglobina & 1.35 & 60 \\
\hline Gelatin & 0.44 & 20 \\
\hline
\end{tabular}

The activity of the studied enzyme was strongly inhibited in the presence of the specific serine protease inhibitors DFP and Pefabloc (Table 4). What's interesting, the metalloprotease inhibitors EGTA (Ethylene glycol tetraacetic acid), EDTA (Ethylenediaminetetraacetic acid), and 1,10-Phenantroline also decreased the activity of the protease. The inhibitors of aspartyl proteases (Pepstatin A) and cysteine proteases (E-64, iodoacetamide) did not affect the activity of the enzyme. Similarly, the trypsin inhibitor Aprotinin did not inhibit its activity.

The divalent metal ions used in the experiments, such as $\mathrm{Mg}, \mathrm{Mn}$ or $\mathrm{Ca}$ caused either slight stimulation of enzymatic activity $(\mathrm{Mn}, \mathrm{Mg}$ ) or its stabilization (Ca). Ions of cadmium, cobalt and copper strongly inhibited activity (Table 5). The effect of detergents and other chemical compounds on the activity and stability of the studied keratinase was also examined. The presence of SDS and Triton X-100 inhibited the activity of the enzyme by 25 and $5 \%$, respectively.
Table 4. Activity of keratinase in the presence of specific inhibitors

\begin{tabular}{|c|c|c|}
\hline Inhibitor & $\begin{array}{c}\text { Concentration } \\
(\mathbf{m M})\end{array}$ & $\begin{array}{c}\text { Residual } \\
\text { Activity (\%) }\end{array}$ \\
\hline none & - & 100 \\
\hline \multirow{2}{*}{ DFP } & 0.1 & 35 \\
\hline & 1 & 12 \\
\hline \multirow{2}{*}{ Pefabloc } & 0.1 & 80 \\
\hline & 1 & 70 \\
\hline \multirow{2}{*}{ PMSF } & 0.1 & 60 \\
\hline & 1 & 20 \\
\hline \multirow{2}{*}{ EDTA } & 1 & 78 \\
\hline & 5 & 65 \\
\hline \multirow{2}{*}{ EGTA } & 1 & 57 \\
\hline & 5 & 45 \\
\hline \multirow{2}{*}{ 1,10-Phenantroline } & 1 & 80 \\
\hline & 5 & 65 \\
\hline \multirow[t]{2}{*}{ Iodoacetamide } & 0.1 & 100 \\
\hline & 1 & 100 \\
\hline \multirow{2}{*}{ E-64 } & 0.1 & 100 \\
\hline & 1 & 100 \\
\hline Pepstatin A & 3 & 100 \\
\hline Aprotinin & 0.1 & 100 \\
\hline
\end{tabular}

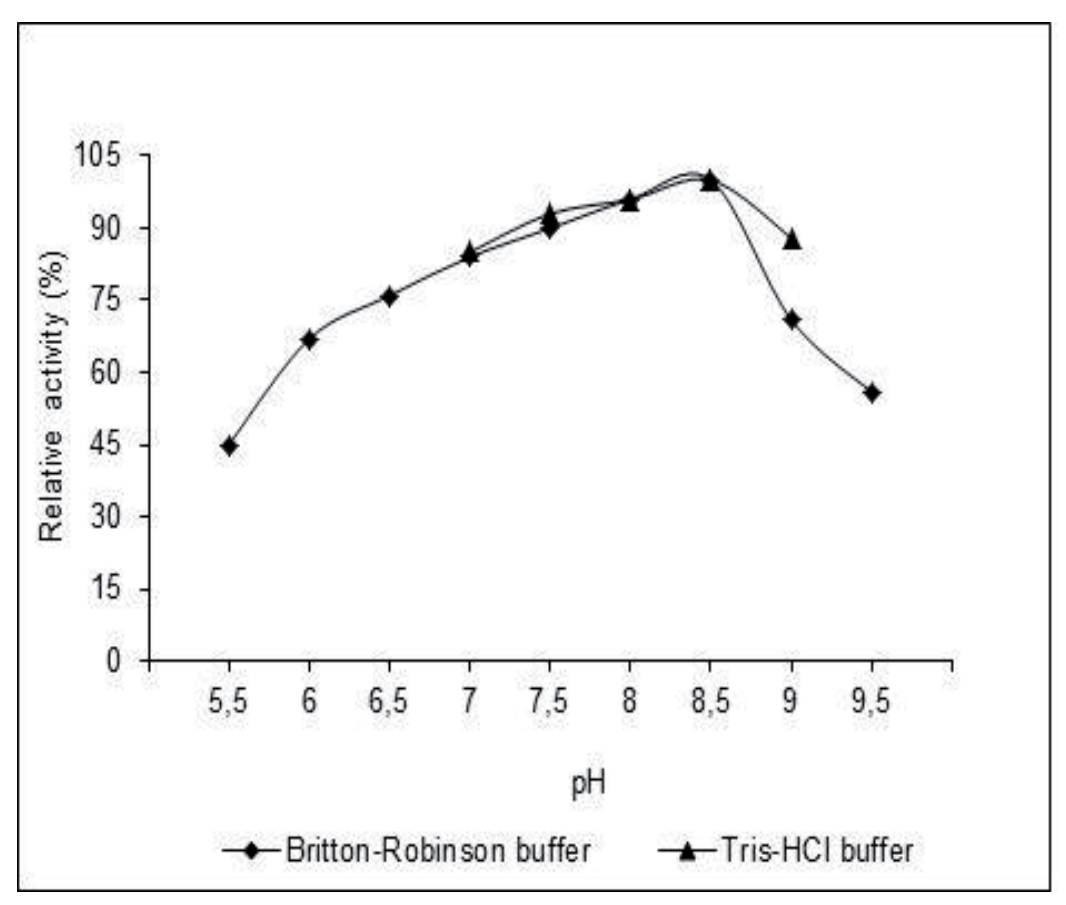

Figure 6. Effect of $\mathrm{pH}$ on the activity of keratinase from S. maltophilia $\mathrm{N} 4$ 
Table 5. Effect of various reagents on the keratinase activity

\begin{tabular}{|l|c|c|}
\hline \multicolumn{1}{|c|}{ Reagents } & Concentrations & $\begin{array}{c}\text { Residual } \\
\text { activity (\%) }\end{array}$ \\
\hline Control & $5 \mathrm{mM}$ & 100 \\
\hline $\mathrm{Mg}^{2+}$ & $5 \mathrm{mM}$ & 120 \\
\hline $\mathrm{Mn}^{2+}$ & $5 \mathrm{mM}$ & 125 \\
\hline $\mathrm{Ca}^{2+}$ & $5 \mathrm{mM}$ & 105 \\
\hline $\mathrm{Zn}^{2+}$ & $5 \mathrm{mM}$ & 45 \\
\hline $\mathrm{Cu}^{2+}$ & $5 \mathrm{mM}$ & 15 \\
\hline $\mathrm{Co}^{2+}$ & $5 \mathrm{mM}$ & 21 \\
\hline $\mathrm{Cd}^{2+}$ & $1 \%$ & 95 \\
\hline $\mathrm{Triton}^{2+} \mathrm{X} 100$ & $1 \%$ & 105 \\
\hline $\mathrm{Tween} 80^{2}$ & $0.1 \%$ & 75 \\
\hline $\mathrm{SDS}^{2-\mathrm{M} \text { EtOH }}$ & $0.5 \%$ & 100 \\
\hline
\end{tabular}

\section{Discussion}

The studied bacterium $S$. maltophilia N4 is very interesting in view of its wealth of extracellular hydrolases as well as characterized chitinolytic activity (Jankiewicz \& Swiontek Brzezinska, 2015; Jankiewicz et al., 2016) and the current study deals with proteases showing keratinolytic activity. The obtained results point to a close dependence between the activity of the bacterial proteases and the composition of the culture medium. A mineral medium supplemented with bird feathers was found to be the optimal growth medium for the production of proteases by this bacterium. This indicates that $S$. maltophilia N4 efficiently utilizes keratin in the feathers as a source of nitrogen and carbon. Of interest is that further enrichment of the growth medium in nutrients readily used by bacteria, such as glucose, peptone or yeast extract did not result in further increase in proteolytic activity and in the case of some of the nutrients used the activity was found to be decreased. Similar observations have been described for cultures of the bacterium Stenotrophomonas sp. D1 (Yamamura et al., 2002). On the other hand, enriching the growth medium of S. maltophilia R13 in additional, besides feathers, sources of carbon was found to increase the observed level of proteolytic activity (Jeong et al., 2010). A review of the obtained results points to the constitutive nature of the production of proteases by strain N4, but that activity is further induced by nonspecific components in the medium, in this case by keratin in the bird feathers. For most of the proteases described so far the inductive nature of their synthesis has been found
(Cao et al., 2009; Gupta \& Ramnani, 2006). The studied protease demonstrated an unusually high temperature optimum compared to the other Stenotrophomonas proteases described. For example, the temperature optimum for the keratinolytic proteases of $S$. maltophilia BBE11-1 was in the $40-50^{\circ} \mathrm{C}$ range (Fang et al., 2013) and protease S1 at $50^{\circ} \mathrm{C}$ (Miyaji et al., 2005).

Optimal pH above 8.0 has been described for serine proteases of both Stenotrophomonas and other species of bacteria (Raval et al., 2014; Paul et al., 2014; Wang et al., 2016) even though many of these enzymes work better in a neutral environment. The studied protease of strain $\mathrm{N} 4$ demonstrated considerable thermal stability at $55^{\circ} \mathrm{C}$, similarly to keratinase KerSMD at $50^{\circ} \mathrm{C}$ (Fang et al., 2014).

The characterized enzyme showed broad substrate specificity with regard to soluble protein substrates but was the most active against casein and keratin, which is confirmed by literature data on the keratinases (Gupta \& Ramnani, 2006). In the case of the studied bacterial protease N4 the $\mathrm{K}: \mathrm{C}$ ratio (keratinolytic : caseinolytic activity), was 0.71 , which according to the accepted principles allow to classify the protease to the keratinases (Gupta et al., 2013; Rajput et al., 2010). For example, Fang et al. (2014) gives a K : C for 1.37 keratinase SMD. Studies with the use of specific inhibitors showed that this is a metal-dependent serine protease. This non-classical mechanism of catalysis was also suggested for the keratinases of S. maltophilia BBE11-1 (Fang et al., 2013) and the keratinase of Streptomyces aureofaciens K13 (Gong et al., 2015). The inhibition of the studied enzyme by metalloprotease inhibitors may point to the participation of metal ions in the enzyme's stabilization or activation. The slight stimulation or stabilization of the activity of the studied keratinase observed in the case of calcium, magnesium and manganese ions was compatible with the results of earlier studies on the keratinase of S. maltophilia L1 (Cao et al., 2009) and in part in with the keratinases of strain BBE11-1 (Fang et al., 2014). The opposite was observed for the activity of the alkaline protease of S. maltophilia SK1, which was completely inhibited in the presence of calcium ions (Waghmare et al., 2015).

\section{Conclusion}

The insensitivity of this protein to surfactants, along with high temperature optimum and thermal stability, suggests that the enzyme may find application in the chemical industry. Moreover, it is important from the practical point of view that the studied enzyme demonstrated a broad substrate specificity and hydrolysed raw keratin waste. All things considered, the described protease is an interesting protein and a suitable candidate for industrial applications. 


\section{Acknowledgement}

The project was funded by the National Science Centre of Poland, decision no. UMO-2011/01/B/NZ9/04555.

We are grateful to Dr Kowalczyk P. (Bionicum LTD, Warsaw, Poland) for advice on proteomic analysis.

\section{References}

Anson M.L., 1938, The estimation of pepsin, trypsin, papain and cathepsin with hemoglobin. Journal of General Physiology 22: 79-89.

Bockle B. \& Muller R., 1997, Reduction of Disulfide Bonds by Streptomyces pactum during Growth on Chicken Feathers. Applied and Environmental Microbiology 2: 790-792.

Bradford M.M., 1976, A rapid and sensitive method for the quantization of microgram quantities of protein utilizing the principle of protein-dye binding. Analytical Biochemistry 72: 248-254.

Brandelli A., 2008, Bacterial keratinases: useful enzymes for bioprocessing agroindustrial wastes and beyond. Food Bioprocess Technol. 1: 105-116.

Brandelli A., Daroit D.J. \& Riffel A., 2010, Biochemical features of microbial keratinases and their production and applications. Applied Microbiology and Biotechnology 85: 1735-1750.

Brandelli A., Sala L. \& Kalil S.J., 2015, Microbial enzymes for bioconversion of poultry waste into addedvalue products. Food Research International. 73: 3-12.

Cai C.G., Chen J.S., Qi J.J., Yin Y. \& Zheng X.D., 2008, Purification and characterization of keratinase from a new Bacillus subtilis strain. Journal of Zhejiang University SCIENCE B 9: 713-720.

Cao Z.J., Zhang Q., Wei D.K., Chen L., Wang J., Zhang X.Q. \& Zhou M.H., 2009, Characterization of a novel Stenotrophomonas isolate with high keratinase activity and purification of the enzyme. Journal of Industrial Microbiology and Biotechnology 36: 181-188.

Fang, Z., Zhang, J., Liu, B., Du, G.,Chen, J., 2013, Biochemical characterization of three keratinolytic enzymes from Stenotrophomonas maltophilia BBE11-1 for biodegrading keratin wastes. International Biodeterioration \& Biodegradation, 82: 166-172.

Fang Z., Zhang J., Liu B., Jiang L., Du G., Chen J., 2014, Cloning, heterologous expression and characterization of two keratinases from Stenotrophomonas maltophilia BBE11-1. Process Biochememistry 49: 647-654.

Fontoura R., Daroit D.J., Correa A.P.F., Meira S.M., Mosquera M, Brandelli A., 2014, Production of feather hydrolysates with antioxidant, angiotensin-I converting enzyme- and dipeptidyl peptidase-IV-inhibitory activities. New Biotechnology 31: 507-513.

Gong J.S., Wang Y., Zhang, D.D., Zhang, R.X., Su C., Li H. \& Shi J.S., 2015, Biochemical characterization of an extreme alkaline and surfactant-stable keratinase derived from a newly isolated actinomycete Streptomyces aureofaciens K13. RSC Advances 5: 24691-24699.

Gopinath S.C., Anbu P., Lakshmipriya T., Tang T.H., Chen Y., Hashim U. \& Arshad M.K., 2015, Biotechnological Aspects and Perspective of Microbial Keratinase Production. BioMed Research International, article ID 140726, 10 pp. (http://dx.doi.org/10.1155/2015/140726).

Gupta R. \& Ramnani P., 2006, Microbial keratinases and their prospective applications: an overview. Applied Microbiology and Biotechnology 70: 21-33.

Gupta R., Sharma R. \& Beg Q.K., 2013, Revisiting microbial keratinases: next generation proteases for sustainable biotechnology. Critical Reviews in Biotechnology 33: $216-228$.

Jankiewicz U., Larkowska E. \& Swiontek Brzezinska M., 2016, Production, characterization, gene cloning, and nematocidal activity of the extracellular protease from Stenotrophomonas maltophilia N4. Journal of Bioscience and Bioengineering 121: 614-618.

Jankiewicz U. \& Swiontek Brzezinska M., 2015, Purification, characterization, and gene cloning of a chitinase from Stenotrophomonas maltophilia N4. Journal of Basic Microbiology 55: 709-717.

Jeong J.H., Lee O.M., Jeon Y.D., Kim, J.D., Lee N.R., Lee C.Y.\& Son H.J., 2010, Production of keratinolytic enzyme by a newly isolated feather-degrading Stenotrophomonas maltophilia that produces plant growthpromoting activity. Process Biochemistry 45: 17381745.

Korniłłowicz-Kowalska T. \& Bohacz J., 2011, Biodegradation of keratin waste: theory and practical aspects. Waste Management 31: 1689-1701.

Łaba W., Kopeć W., Chorążyk D., Kancelista A., Piegza M. \& Malik K., 2015, Biodegradation of pretreated pig bristles by Bacillus cereus B5. International Biodeterioration and Biodegradation 100: 116-123.

Laemmli U.K., 1970, Cleavage of structural proteins during the assembly of the head of bacteriophage T4. Nature 227: 680-685.

Lasekan A., Bakar F.A. \& Hashim D., 2013, Potential of chicken by-products as sources of useful biological resources. Waste Management 33: 552-565.

Miyaji T., Otta Y., Shibata T., Mitsui K., Nakagawa T., Watanabe T. \& Tomizuka N., 2005, Purification and characterization of extracellular alkaline serine protease from Stenotrophomonas maltophilia strain S-1. Letters in Applied Microbiology 41: 253-257.

Paul T, Das A., Mandal A., Halder S.K., DasMohapatra P.K., Pati B.R. \& Mondal K.C., 2014, Biochemical and 
Structural Characterization of a Detergent Stable Alkaline Serine Keratinase from Paenibacillus Woosongensis TKB2: A Potential Additive for Laundry Detergent. Waste and Biomass Valorization 5(4): 563-574.

Prakash P., Jayalakshmi, S.K. \& Sreeramulu K., 2010, Purification and characterization of extreme alkaline, thermostable keratinase, and keratin disulfide reductase produced by Bacillus halodurans PPKS-2. Applied Microbiology and Biotechnology 87: 625-633.

Rajput, R., Sharma, R. \& Gupta, R., 2010, Biochemical characterization of a thiol-activated, oxidation stable keratinase from Bacillus pumilus KS12. Enzyme Research 2010: 1-7.

Rao M.B., Tanksale A.M., Ghatge M.S. \& Deshpande V.V., 1998, Molecular and biotechnological aspects of microbial proteases. Microbiology and Molecular Biology Reviews 62: 597-635.

Raval V.H., Pillai S., Rawal C.M. \& Singh S.P., 2014, Biochemical and structural characterization of a detergentstable serine alkaline protease from seawater haloalkaliphilic bacteria. Process Biochemistry 49: 955-962.
Sawant R. \& Nagendran S., 2014, Protease: an enzyme with multiple industrial applications. World Journal of Pharmacy and Pharmaceutical Sciences 3: 568-579.

Vojcic L., Pitzler C., Wirtz G., Jakob F., Martinez R., Maurer K.H. \& Schwaneberg U., 2015, Advances in protease engineering for laundry detergents. New Biotechnology 32: 629-634.

Waghmare S.R., Gurav A.A., Mali S.A., Nadaf N.H., Jadhav D.B. \& Sonawane K.D., 2015, Purification and characterization of novel organic solvent tolerant $98 \mathrm{kDa}$ alkaline protease from isolated Stenotrophomonas maltophilia strain SK. Protein Expression and Purification 107: 1-6.

Wang Z., Sun L., Cheng J., Liu C., Tang X., Zhang H., Liu Y., 2016, The optimization of fermentation conditions and enzyme properties of Stenotrophomonas maltophilia for protease production. Biotechnology and Applied Biochemistry 63: 292-299.

Yamamura S., Morita Y., Hasan Q., Yokoyama K. \& Tamiya E., 2002, Keratin degradation: a cooperative action of two enzymes from Stenotrophomonas sp. Biochemical and Biophysical Research Communications 294: 1138-1143. 